\title{
Abraham Narrative through the Structure of Turn Over
}

\author{
Saya Lee \\ Department of General Education, Namseoul University, Cheonan 580-2302, Korea \\ isaiah37@naver.com
}

\begin{abstract}
Story of Abraham, which starts the history of head of families, implies three covenants that the Creator gives to Abraham. Three covenants are: (a) a promise that the land of Canaan belongs to Abraham, (b) a promise that the family of Abraham will become a great nation like stars in the sky and sands in seashore, and (c) a promise that all peoples in on the ground will have His prosperity. It is important to know when three covenants were fulfilling. Specifically, it is important to understand that history in Bible is specified as salvation history. Based on the relationship between covenants and fulfillments, this study applies the story of Abraham that has three "turn over" events into the modern society.
\end{abstract}

Keywords: Abraham, Turn-over, Promise, Egypt, Laughter

\section{Introduction}

Covenants between the Lord and Abraham had not been accomplished during the period when Abraham had been still alive. It had taken long time to accomplish the covenants and there had been needed three turn-over events to fulfill the covenants. First, Abraham yields his land of Canaan to Lot which is his nephew. However, Lord restore all land of Canaan to Abraham (Genesis 13:14-15). Second, a bitter smile changes to joyful guffaw when Isaac was promised to be born (Genesis 21:6). Third, on the Altar in the Mountain Moriah, the Lord saves Isaac from the death. This study revisits the three consecutive events by using hermeneutics so that the meanings of the events can be employed in the modern society and churches.

\section{Turn-over one: From the safe-zone of mankind to the safe-zone of the Lord}

The Abraham story is somewhat episodic in character-more so than the stories of Jacob and especially Joseph will be-and it is difficult to discern how everything coheres.[1] The Lord instructs Abraham to get out of "the homeland," "the relatives," and "the father's lands," and the Lord orders to go "unto a land that I will shew thee." The order is significantly meaningful and unique because the family, bloods, and place of birth are decisive factors of a person's fate and status in an ancient era. Compared to modern period when a geographical mobility is frequently occurred, ancient people live in one place for their whole life. It implies that there are few interactions and relationships among various towns. It makes the local dialogues and local unique cultures since each town stands alone for a long time without interacting with other

Article history:

Received (March 1, 2019), Review Result (April 28, 2019), Accepted (May 23, 2019) 
towns. Therefore, the bloods and the place of birth are representative two decisive influences that decide a natural person's fate.

However, the Lord instructs Abraham to get out of the homeland and his father's lands where Abraham belongs. Considering Abraham's status of natural person, the homeland and father's land mean the protective area which is made by mankind. The Lord commands Abraham to leave the protective area constructed by mankind. The Lord orders Abraham to form his own new people in the new place where the Lord indicates. In other words, the Lord let the Abraham move from the old area protected by mankind to the new area protected directly by God. From the moment, the protective system that Abraham needs is not safety by mankind but safety by God. This event means that Abraham gets into the new life of faith and becomes a new person of faith by believing in God. Under being safeguarded by the Lord, the great nation of Abraham will be accomplished as following the Lord's covenants.

Abraham needs to make a brave decision-making when he moves from the land of Haran to the land of Canaan. Ur, where is the Abraham's original hometown (Genesis 11:26), and Haran, where is his father's land, are highly civilized areas. However, the land of Canaan is the barely land where the low civilization stage is extremely low. In short, it is similar with the case that a person moves from a metropolitan area to the rural barely land without electronics.

The land of Ur in Chaldea is affluent area with high civilized culture. Specifically, Ur is a center of Sumer civilization since there are affluent resources from delta area of Euphrates River. Haran is located $950 \mathrm{~km}$ away from Ur. The city is one of the most developed commercial cities of northern Mesopotamian area. Compare to Ur and Haran, the land of Canaan is impoverished with low level of material resources. However, by following the Lord's order to move from Ur to Canaan, the covenants given to Abraham was not only the strong descendant but also the land of Canaan belonging to the descendant (Genesis 12:7; 13:14; 15:7; $17: 8)$.

The first job that Abraham has done right after returning from Egypt was letting Lot go away from him. The presence of Lot, Haran's son, is emphasized from the beginning and at each stage of the journey in and through Canaan.[2] Before parting from Abraham, Lot has accompanied him for a long time. Even in the harsh time including the first arriving at Canaan, Lot has magnificently accompanied Abraham for looking foods without any debates. However, the foundational issue between two has been existed on 'group' instead of 'individual.' When they escaped from Egypt, Abraham and Lot owned too much properties to have them in the limited land of Canaan. The limited land of Canaan causes the debate between two groups, Abraham's people and Lot's people. Although the situation can be seemed to be reverse case of the Lord' covenant that Abraham will have "a great nation," Abraham suggest Lot to divide two parties (Genesis 13:8-9). Generally, the initial issues of social ills are caused by materials. When the debate between Abraham's party and Lot's party happens, there has been other peoples (i.e., including Canaan people and Perizzites people) engaged in the debates even though these peoples are not related with the Lord's covenants (Genesis 12:7). In addition, Isaac had to tolerate the jealousy Philistine people who are not knowing the Lord (Genesis 26:12-25). By showing these provocative situations, context in the Bible describes the uniquely 'different' feature of Abraham who is belonging to God. The unique feature of Abraham, which is described in the Bible, is not same as previous Abraham who sacrificed his wife for his surviving. Rather, at this moment of debate with Lot, Abraham sacrifice himself for solving the issue. First, Abraham emphasizes that they are relatives (Genesis 12:8). The relatives have two contentious meanings that, (a) they 'should not debate' because they are close with the same bloods and (b) they are 'not allowed to stay together' because of belonging to "relatives and father's land." After sending Lot, the relationship between Abraham and the Lord is regenerated. 
It is that the Lord let Abraham reconsider Canaan as his land of covenant. When Abraham follow the Lord's instruction that he should get away from his past evil habit, God keep executing His covenant on him.

Likewise, the current social ills are occurred by the ownership of materials. In the past, church communities/leaders were worrying about the social ills. However, nowadays, there has been a criticism that social communities/leaders are worrying about the church communities/leaders. There are two divisions, divinity that belongs to God and secularity that belongs to the world. In the past, divine people concern about the secular worldliness. However, currently, the secular people concern about inappropriate divine people. It is caused by that church leaders and communities are not working properly inside of God's order but seeking the shameful worldliness.

Returning to story of Abraham and Lot, Abraham yields his right of deciding the land to live and offer Lot to choose the land first. In other words, Abraham gives up his vested right to choose the affluent lands. By accepting Abraham's offer, Lot choose the affluent lands and leave toward the prosperous lands. After Lot's leaving, the Lord gives His word that He will stretch Abraham's lands toward all directions (i.e., east, west, south, and north) including Lot's direction (i.e., east). Abraham abandoned his right to the earth, but eventually all the earth was his own (Gen. 13:15). Abraham, for the most part, was able to leave the human protection area and enter the protection area of God.

The promise of the land is reinforced by purchasing land for the burial site at the end of the Abraham story.[3] The Lord's covenant that He will give all land of Canaan to Abraham is succeeded to Abraham's descendant, Isaac and Jacob (Genesis 26:3; 28:13; 35:12). To Abraham and his descendants, it is obvious divine bless that the Lord give His word of allowing permanent ownership of the land of Canaan. However, the first concerned of His word, Abraham, is not becoming the first recipient of the ownership. In Genesis 23, a scene shows the gap between Abraham's reality and the Lord's covenant. Even though Abraham gets His word that he will own the land of Canaan, he can't find even a small land for burying his lovely wife, Sarah, for her death. Therefore, for burying his wife, Abraham buys a cave (i.e., Machpelah) from a Hittites (i.e., Ephron) with paying 400 shekels of silver. The cave of Machpelah becomes a cemetery for Abraham, Isaac, Rebekah, Jacob and Leah, which are all main characters of Old Testament. Until fulfilling the covenants about the lands on descendants of Abraham, it has taken long time to accomplish. The Lord's covenant does not mean an immediate accomplishment of miracle that people want to have on exact time and exact place. Sometimes, the covenants need long time to accomplish although it seems to be vanished in the perspective of people. The fulfilling method is sometimes beyond over the people's expectations.

In the perspective of mankind, after leaving from the "homeland" and "father's land," it is risky choice to let Lot go away. It means that Abraham is giving up the safety by separating with the closest relatives. Specifically, in ancient West Asia, it is too risky to live as drifter without legal protection. In addition, it is also too risky to separate with close relatives. The situation surviving alone as drifter in West Asia means push oneself into the harsher situation. However, the case of Abraham in the land of Canaan shows the turn-over story. Abraham gives up his vested right on the land but, eventually, the land of Canaan becomes Abraham's land. Abraham gives up his safety in terms of mankind but, eventually, he resides into the protection of the Lord.[4]

\section{Turn-over two: From bitter laughter to delightful laughter}


After leaving Lot, Abraham experiences many events in a long time waiting for the fulfillment of the promise. If we look at the events that have been recorded, obviously God promised Abraham countless generations (Gen 12: 2; 13:16; 15: 5; 22:17). Because Abraham's wife, Sarai, is a woman who can not conceive (Gen 11:30), he hastened to the promise of this incredible God. Genesis 17 begins by once again emphasizing the age of Abraham. Abraham was already at the age of ninety-nine. This emphasis on Abraham's aging is in his attempt to show that there is no hope for posterity in human ability.

This hopeless old man Abraham and his wife Sarah react with laughter in God's promise that a son will be born. But it was not a laughing delight in expectation of a child, but a bitter laugh that had already given up all hope (Genesis 17:17).

Finally, the promise of God had a long wait. During the time God spoke, Sarah was pregnant and had a son (Genesis 21: 1-2). Abraham's "old age" is contrasted with God's "Word" in a short passage in which Sarah, who lost her capacity as a woman, gave birth to a son. Sarah, who has her son Isaac in her arms, calls out "God makes me laugh" (Gen 21: 6). This laughter is no longer a bitter laugh of life. It is the laughter of joy that bursts out of the faithfulness of God. This laugh is the laughter of the reversal that God already knew. And the reversal of turning human bitter laughter into joyful laughter is still ongoing.

\section{Turn-over three: From Past to Future}

The paragraph that forms the most dramatic reversal in Abraham's story is the obedience to God's command to sacrifice Isaac. God commands Abraham to offer special burnt offerings on the mountains in the land of Moriah (Gen. 22: 1). The triple structure of "Your son, your beloved one and only, Isaac" resembles a similar structure to the "home of the mainland, relatives, and Father's house" (Gen 12: 1). If the command in Genesis 12 requires disconnection from the past, then the command in Genesis 22 calls for a break with the future. As Abraham builds an altar and ties his son Isaac and takes his life, God dramatically intervenes and reverses the situation. Abraham's obedience to the Word of God adorns the beginning and end of the story (Genesis 12:22).[5] According to the interpretation of the Jews, this was not Abraham trying to overthrow his son Isaac, but his son Isaac actively obeyed his father.[6] Isaac was strapped to Abraham by himself.[7] This third reversal in Morias is dramatically resembling the most dramatic event in the New Testament, Jesus' Golgotha. Jesus' crucifixion on Golgotha Hill is the event in which Jesus, the Son, actively obeyed the will of the Father, and died.

\section{Conclusion}

There are three promises between Abraham and God in the story of the patriarchs of the Old Testament. First, God will give land to Abraham who has left their stable home by faith and has gone to the land God has directed. Second, the descendants of Abraham will increase. Third, all the tribes of the earth will be blessed by Abraham. Indeed, those promises were fulfilled one by one in the history of the Bible. The process of fulfillment of these promises is accompanied by several reversal stories. It is a reversal from despair to hope. The first promise was fulfilled in Joshua's Canaan occupation. Dtr. Historians Say that "Israel has given all the land that YHWH swore to the fathers of Israel to give" (Joshua 21:43). In the sense that the promise that originated in Genesis was not realized until Joshua crossed the Pentateuch, von Rad also derived the concept of Hexateuch rather than Pentateuch. [8] There is a tremendous difference between saying that man conquered by his power and God gave. Second, the promise to the descendants is realized in the Exodus. After all the descendants of Abraham in Genesis died, the community of Israel fell from slavery in Egypt. Although the environment was desperate, 
God's promise was preparing a new history for Israel. The Israelites became numerous and filled the whole earth (Exodus 1:7). The promise of his descendants was fulfilled outside Canaan. The last third promise, that all the tribes of the earth would be blessed, was realized only after many years passed in the time of Jesus. This is an important material for the continuity of the Old Testament and the New Testament. The stories of Abraham's reversal are presented as the message of hope that the Israeli community experiencing exile can rise again after disaster and pain.

\section{Acknowledgements}

Fund for this paper was provided by Namseoul University.

\section{References}

[1] Terence E. Fretheim, The Pentateuch, Abingdon Press, pp.85 (1996)

[2] Joseph Blenkinsopp, The Pentateuch, NewYork: Doubleday, pp.101 (1992)

[3] Terence E. Fretheim, The Pentateuch, Abingdon Press, pp.120 (1996)

[4] Saya Lee, "Abraham revealed through the stories of journeys and building altars", Theological Forum 60, Seoul: Yonsei Univ., pp.113-114 (2010).

[5] Terence E. Fretheim, The Pentateuch, Abingdon Press, 123 (1996)

[6] M. Klein, The Fragment Targums of the Pentateuch According to their Extant Sources, Biblical Institute Press, pp.83 (1980)

[7] E. Kessler, Bound By the Bible: Jews, Christians and the Sacrifice of Isaac, Cambridge University Press pp.123 (2004)

[8] G. von Rad, Genesis: A Commentary, Westerminsterpress, pp.77 (1972) 
Abraham Narrative through the Structure of Turn Over 